\title{
Crippin' the Flâneur: Cosmopolitanism, and Landscapes of Tolerance
}

Fiona Kumari Campbell

Griffith University

\begin{abstract}
Cosmopolitanism, desire and the contracting of social relationships are enduring themes in both philosophy and social theory. In this paper I seek to explore these themes in order to ascertain what they might mean to disabled people and the ethos of ableism more generally. Modern Westernized life has since the Industrial Revolution been sited in cities fostering the growth of urban culture and an ethos of cosmopolitanism (Agamben, 2009; Beck, 2002; Cheah, 2006). The cosmopolitan outlook has become the signifier of that which is developed, advanced and civilized in society. The liberal project of the melting pot, of social tolerance is cast against the backdrop of city life (Brown, 2006). The paper will first examine the trope of cosmopolitanism and disability including the place of 'spaces' for marginal peoples. Second, it will provide a perspective on the disabled flâneur (Campbell, 2009; Simmel, 1908; Young, 2005) who ambivalently claims 'outsider-insidedness' and finally the paper moves to consider the significant question of social inclusion and the government of aversion through the deployment of discourses of tolerance.
\end{abstract}

Keywords: cosmopolitanism; social inclusion, community, flâneur, tolerance; biopolitics; disability

If the humanities has a future as cultural criticism, and cultural criticism has a task at the present moment, it is no doubt to return us to the human where we do not expect to find it, in its frailty and at the limits of its capacity to make sense. We would have to interrogate the emergence and vanishing of the human at the limits of what we can know, what we can hear, what we can see, what we can sense. (Butler, 2004, p. 151)

Cosmopolitanism, desire and the contracting of social relationships are enduring themes in both philosophy and social theory (Benhabib, 2004; Doran, 2009; Popewitz, 2008). In this paper I seek to explore these themes in order to ascertain what they might mean to disabled people and the ethos of ableism more generally. Modern Westernized life has since the Industrial Revolution been sited in cities fostering the growth of urban culture and an ethos of cosmopolitanism (Agamben, 2009; Beck, 2002; Cheah, 2006). 
The cosmopolitan outlook has become the signifier of that which is developed, advanced and civilized in society. The liberal project of the melting pot, of a social tolerance is cast against the backdrop of city life (Brown, 2006). The paper will first examine the trope of cosmopolitanism and disability including the place of 'spaces' for marginal peoples and the trope of hospitality. Second, it will provide a perspective on the disabled flâneur (Campbell, 2009; Simmel, 1908; Young, 2005) who ambivalently claims 'outsider-insidedness' and finally the paper moves to consider the significant question of social inclusion (its paradoxes and guilt) and the government of aversion through the deployment of discourses of tolerance.

\section{Cosmopolitanism - a Higher Form of Life?}

Cosmopolitanism, the teleological ethos of human sophistication brings to the surface certain limits about modern life, what we should be, what kinds of norms we should emulate and forms the basis of community and the texture of its borders. At its hub is the Stoic idea of the kosmopolités, or the citizen of the world. As Lucius Seneca (4 BCE - CE 65) puts it "truly great and truly common, in which we look neither to this corner nor to that, but measure the boundaries of our nation by the sun" (Seneca, 1987, p. 431). This calling forth, where 'all' are in our sphere of concern and obligation induces an exilic status away from the comforts of homosociality, "the warm nestling feeling of local loyalties” (Nussbaum, 1997, p. 11).

More recently such a sentiment is typified in the Live Aid Ethiopian famine popular song catchcry of 1985 "we are the world, we are the children ...."1 (Westley, 1991). In eighteenth century Europe cosmopolitanism denoted an attitude of openmindedness and impartiality, where there was a sharing of reason and the capacity to experience pleasure, pain and imagination among free men $^{2}$. Such a moral view of cosmopolitanism takes its origin from Stoic thought which sees respect and moral recognition as paramount.

Universalism and social inclusion can be regarded as key subsets of the cosmopolitan ideal: "the cosmopolitan embrace of social inclusion was elaborated in order to progress towards (Kant's) perpetual peace housed in the virtues of a globally democratic citizenship ...” (Doran, 2009, p. 175). Community and moral citizenship however were outside of any developments in the State (political citizenship). Hence, cosmopolitanism was not necessarily endorsing a metropolis of communitarian equity. Unlike Christoph Wieland $(1733$ - 1813) who distinguished between 'world dwellers' and 'world citizens' (the sages/teachers), Emmanuel Kant (1724 - 1804) is somewhat more egalitarian suggesting that all humans are citizens and that each can undertake moral discernment (Kleingeld, 1999). Urban convergences as sites of social integration and tolerance can be juxtaposed with a topography, the whole earth which has undergone processes of clearances and enclosures, the fencing of space which "has almost completely divided up between public and private property" (Hardt \& Negri, 2009, p. vii). Herein land has been drafted as a forcefield for exclusion with the addition of no-go and anomalous zones. Later in this paper I discuss the figure of the cripped flâneur and how this person makes sense of enforced space.

Whilst cosmopolitanism should not be simply bifurcated as hospitality, Kant's convergence of the two is significant. Kant proposed a project of a cosmopolitan right to hospitality. For Kant hospitality was not seen as a form of social engagement, but as a right (Kant, 2007, org 1795, II, $3^{\text {rd }}$ Definitive Art, p. 21). Cosmopolitan hospitality is not a virtue of sociability and does not regulate relationships between 
'insiders', that is, members of homosocial groups; rather hospitality based on a problematic of alterity

... regulates the interactions of individuals who belong to different civic entities who encounter one another at the margins of bounded communities. A cosmopolitan ethic acts as a reminder of belonging to humanity beyond a singularity of identity. The right of hospitality is situated at the boundaries of the polity; it delimits civic space by regulating relations among members and strangers. (Benhabib, 2004, p. 27)

Cosmopolitanism is a quality of exile and strangeness to one's self through reflection. As an encounter of not knowing, cosmopolitanism is not easily cultivated. It is this regulation of the conduct of conduct in cosmopolitanism that I argue has the capacity to rethink and thus contribute to the undoing of ableist exclusions. The ancient Stoics and Cynics, whilst diverse thinkers, believed in cultivating a disposition where our belongingness to humanity should direct our conduct and outweigh other divisive attributes such as class, gender and origin (Nussbaum, 1997, p. 5). Obligation to others becomes co-operation in the form of alleviation of suffering and moral education for all.

The Stoic worldview incorporates an inclusivity based on a chain of being among humans who are linked by a 'divine breath' (Aurelius, 1919, VII, 9, pp. 136 137). Marcus Aurelius (121 -180 CE) Roman Emperor and Stoic philosopher, is firm in suggesting that co-operation extends to being with other humans even if they are belligerent or lacking in virtue (Aurelius, 1919, VI, 42, pp. 130-131.) The universe he argues is sociable (V, 30, p. 117). Humans acting in their singularity (rampant individualism or homosocial) are compared to an amputated hand (VIII, 34, p. 158), for the collective human is constitutive of the individual - like the limb which is constitutive of the body and not merely reckoned as an atomistic part (VII, 13, p. 137). Flourishing then is both cosmopolitan and integrative. The integrative trend of cosmopolitanism has been given new life by scholars who focus on social processes and institutions, as Douzinas (2007, p. 135) puts it, this cosmopolitanism represents “... globalisation with a human face”.

Cosmopolitanism is a mode of organising difference - a space of belonging and separateness, where the productive body recreates, desires or produces. There is however a double gesture, a paradox that purports to include and in the process, excludes. At the global level universal benevolence and humanitas ${ }^{3}$ can act as a big stick for (in)corporation which frames and frames out belligerent States and cultural thought. Dikeç (2002) warns of being uncritical of the notion of hospitality, suggesting that the concept is assumed to be positive and a ready remedy to alleviate so-called burden. In a similar vein we may ask whether inclusion is a remedy or gloss over abjection? Žižek (2008) has raised similar concerns about the role of the rhetoric of tolerance in detracting from issues of poverty and inequality. Beck (2002) in contrast to moves towards territorialism (nationalism) suggests a borderless cosmopolitanism where it is possible to imagine alternative ways of life and rationalities. Hence as a check on conceptual reductionism, thinking about cosmopolitanism needs to be linked with an understanding of biopolitics. Cities are meant to be sites of transgression where there is the possibility of incessant choice between products, people and even temporal enactments such as the fluidity between night and day as times of work and leisure. 
Cosmopolitanism has been given new currency through the work of Hardt \& Negri who view society as radically plural (cosmopolitan), as "a multiplicity of irreducible singularities” which may or may not act in unison (2009, p. 166). Hardt \& Negri refer to relations of cosmopolitanism along the lines of the multitude who due to their characterisation as the poor, stand in opposition to the dominant relations of property sited in the State (2009, p. 39). The multitude are the new proletariat, a heterogeneous web of workers, immigrants, social movements, and non-government organisations. Whilst the visibly excluded form the multitude - the term becomes affirmative to incorporate "an open, inclusive social body, characterized by its boundlessness and its originary state of mixture among social ranks and groups" (p. 40).

Read against the grain in a negative turn, the multitude could denote a 'silent majority', that homosocial convergence who are affronted by a shift to equity in diversity. However returning to Hardt \& Negri, the multitude may have some kind of flâneurial existence (I am not attempting to conflate Simmel with their work). The multitude is a process, an assemblage in the making "constantly transformed, enriched, constituted by a process of making” (Hardt \& Negri, 2009, p. 173). In this process, a metamorphosis of new subjectivities (social singularities) emerge (Campbell, 2008, p. xii). One character arising out of the multitude is the disabled person in the form of the flâneur. Combined, they form the cripped flâneur who despite being under constant erasure can act as a familiar bystander and commentator. In the next section I focus on urban life and civility in a particular reading of the figure of the flâneur with disability.

\section{Crips Moving through Urban Life}

Disability rhetoric correctly postures that disability is an afterthought (Goggin \& Newell, 2005) bound to an exclusionary ableist matrix that sets the terms of engagement. The working model of inclusion is really only successful to the extent that people with disabilities are able to 'opt in', or be assimilated (normalized). A drive towards self-mastery may mean that it is not possible for some disabled people to be truly 'free' within the confines of liberalism. These people may lose person status because they fail to meet certain criterion. Under liberalism, the production and governing of disability is facilitated, in part, through its morphing into a mere logical and discrete etiological classification and ensuing ontological space. Although disability characterises a significant portion of the multitude (between $20-40 \%$ of the population on some reckoning) it is driven down through a process of actuarial reductionism to be 'discreet and insular' (appended to around 13\% of the population) - becoming exceptional rather than usual. The performative acts of the 'logic of identity' reduce the disparity and difference of disabled bodies to a unity (see Foucault, 1980, p. 117). This model of inclusion assumes that the people who cannot, do not, or otherwise refuse to, 'opt in', will developmentally progress towards autonomy over time. Whilst there has been work on the built environment and cities, most notably Gleeson (1999) and Imrie (1996) which recognises that disabled people have always been part of the city, it is the terms of their exclusion and the origin of their invisibility that needs further scrutiny.

Tendencies toward disability are put out by pathologizing desire. ${ }^{4}$ Certain kinds of aberrancy radically disturb, challenge and support the notion of disability as harm which interpolates in the politics of disability as offence and characterologically in turn - disability as offensive brings out the tension between cosmopolitanism and 
the rhetoric of inclusion. Spatiality and access to the city is inhibited by an enduring attitude that disability is tentative and can ultimately be cured or treated. This has induced a sense in the development industry that not only is access expensive it is ultimately a waste of time. (Campbell, 2009; Imrie, 1996). There is another way of orientating disability, being disabled within an ableist trajectory, that of acting as the bystander, a commentator in the form of the sociologically elusive flâneur. Georg Simmel (1908, p. 134) writing in a different context and time describes

... the wanderer, so to speak, who, although he has gone no further, has not quite got over the freedom of coming and going. He is fixed within a certain spatial circle - or within a group whose boundaries are analogous to spatial boundaries - but his position within it is fundamentally affected by the fact that he does not belong in it initially and that he brings qualities into it that are not, and cannot be, indigenous to it.

I am grasping the flâneur, recognising that the figure has an historical and locational context. There is an unpredictability to the flâneur. Of course there are different takes on the flâneur relating to his receptivity towards others. Self absorption is complex, for while there maybe limited recognition by the flâneur of other flâneurs in the metropolis, Williams argues that “... the flâneur must take into account the tales of fellow-flâneurs and competitors, a conceptual and spatio-temporal impossibility which spells doom for all master-narratives and paradigmatic discourses" (1997, p. 821). Certainly survival in the city amongst homeless people and marginal dwellers is very dependent upon the transmission of cultural memory and subjugated knowledges about opportunities, services and dangers (Dunn, 2003; Harter, Berquist, Titsworth, Noval \& Brokaw, 2005; Rowe, Kloos, Chinman, Davidson \& Cross, 2001).

The flâneur embraces the conundrum of alienated belongingness, being an outsider with insiderness. She is both constituted as well as dispossessed by the impulse towards belongingness (Butler, 2004, p. 24). Her radical outsideredness enables her to apprehend and as well become an object that is apprehended. The existence of disability bios (a proper way of living), puts out fear and possibility. Consider the honour of being spectacle, where the staree becomes a stance of resistance for instance, the self managed freak show performance or disability/crip culture (see Figure 1). Pivoting the starer turns toward and turns away.

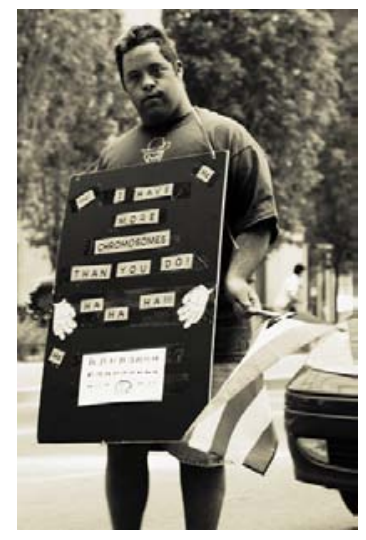

Figure 1: Disabled \& Proud - I Have More Chromosomes Than You Do!

Source: 4th Annual Disability Pride Parade in Chicago 2007. Photo: Sunil Chatur, Accessed 01/01/2010, http://farm2.static.flickr.com/1015/884189913_edf94f142d.jpg 
This is the conflict over liminality that many disabled people experience. Imposed margins that erase until one conforms to ableist norm emulation, places where the zones of exception are sub-standard inducing melancholy. How does the person with a disability negotiate the expectations and compulsions of Ableism? In other words, do they choose to conform or hypermimic ableism or do they go it alone and explore alternative ways of being? People with impairments have impairment mediated proprioceptive ways of experiencing being in the world. In contrast there is the unspeakability of communality and commonality where disabled people can, as Overboe does in his spasms that "give [him] great joy... [becoming] a life-affirming presence” (2007, p. 221).

On guard against romanticization, the boundary rider smugly oscillates in and out of the margins of deviancy. Walter Benjamin in exploring the characters of the metropolis looked to the margins - "he singled out the flâneur, prostitute, collector historical figures whose existence was precarious economically in their own time .... The dynamics of industrialism ultimately threaten these social types with extinction" (Buck-Morss, 1986, p. 101). These are the people who even today are relegated to the dirty jobs typical of workhouses and sheltered workshops. It is this status of precariousness that I believe works to extend flâneurism to disability. Disabled people often lived precariously both economically and ontologically relying on the existence of a prevailing ethos of goodwill. Campbell compellingly argues "[a]ll these people are in effect strangers in ableist homelands - who because of their strangeness have the possibility of a new vision or orientation" (2009, p. 161). Indeed disabled people throughout urbanized history have carried on the role of the subaltern flâneur who is included in his exclusion and whose defining characteristic is not in the expression but rather in the desire (Young, 2005). It would be easy to see the flâneur as the prophet, who stands apart, instead the flâneur just goes about, just 'is'. Simmel again stresses that:

... the stranger is an element of the group itself ... an element whose membership within the group involves both being outside it and confronting it. ... Factors of distance and revulsion work to create a form of being together. (1908, p. 144)

Here it can be argued that that the flâneur as an exception does not validate the rule of the group, rather the flâneur as an exception is contained within the rules of public life (cf. Ewald, 1992). Urban landscapes are littered with disabled street sellers who are at once revealed but veiled. These flâneurs as Wilson (1992, p. 94) puts it "spends most of [their] day simply looking at the urban spectacle". Present but anonymous, the flâneur acts as "a solitary onlooker” (p. 95). Unlike the Muselmann of the Nazi death camps who is obliterated, the solitary onlooker is noticed even in the form of a stare. The flâneur is not always a romanticised image, and has been figured as lapsing into a kind of retreatism. In 1857, de Rattier referred to the flâneur as a non-entity, "constant rubberneck" an "inconsequential type" (Benjamin, 1973, p. 54). This gloomy casting recalls the figure who roams not the streets but the confinement of the camp who is ontologically terrifying because he is questionable:

...non-men who march and labour in silence, the divine spark dead in them, already too empty to really suffer. One hesitates to call them living: one 
hesitates to call their death death, in the face of which they have no fear, as they are too tired to understand.” (Agamben, 1999, p. 44)

The flâneur in Poe's (1912) poem 'The Man of the Crowd' does not have an independent existence of other human beings, but this does not mean he has an enabling interpenetrative relation with them. This flâneur is a sign of life lived as tentative and precarious. The excluded are not just to be found in their banishment, cities have always contained banned persons who intermingle but by being denied political life (zoe), and in their ambivalence, are erased or disappeared. As Wilson (1992) retorts:

The society which thus constituted itself as a spectacle was a society of outsiders, and the boulevards and cafes offered ... a homeland for these individuals without a home. (p. 96)

We are so used to the wanderer being seen as a cast (banished) entity it would be easy to see him as an alien. Simmel points to the paradox of the flâneur being our own excluded [person] and thus represents something of us that is put out:

Included in his exclusion: the stranger is an element of the group itself ... an element whose membership within the group involves both being outside it and confronting it ... factors of distance and revulsion work to create a form of being together. (Simmel, 1908, p. 144)

The flâneur unveils the inclusion of cosmopolitanism to the extent that his suffocation is contrasted. Cosmopolitanism is an ethos that shapes the flâneurian landscape which insinuates possibility and also a fear of degeneration and decay (Popewitz, 2008). Again Poe's narrator in 'The Man of the Crowd' captures this paradox well:

... there arose confusedly and paradoxically within my mind, the ideas of vast mental power, of caution, of penuriousness, of avarice, of coolness, of malice, of blood-thirstiness, of triumph, of merriment, of excessive terror, of intenseof extreme despair. I felt singularly aroused, startled, fascinated. 'How wild a history,' I said to myself, 'is written within that bosom!' Then came a craving desire to keep the man in view_to know more of him. (Poe, 1912, p. 105)

The tension is very real for nuances of neoliberalism are not just about economic relations shaping social and political relations, but that the point of focus is not as in Poe's time, exchange, but rather competition (Foucault, 2008, p. 12). Living in the now and not yet, as outsiders not quite inside; requires a disposition or habit of contemporariness. Contemporariness signifies a relationship with the present but also a distance, a critical space from it. As Agamben explains:

Those who are truly contemporary, who truly belong to their time, are those who neither perfectly coincide with it nor adjust themselves to its demands. They are in this sense irrelevant [inattuale]. But precisely because of this condition, precisely through this disconnection and this anachronism, they are more capable than others of perceiving and grasping their own time. (2009, p. 40) 
The notion of disconnection is not the same as disengagement. The flâneur "knows he is the face in the crowd. And, as such, by virtue of that very knowing, the poet is a man apart even though he might well appear to be a man like any other (Tester, 1994, p. 4). In that way the flâneur is an exemplar of Agamben's contemporary person. A queering of contemporariness is the grasping and holding tight to ambivalence and obscurity which is so fundamental to the alternate lifestyle. This is obtained through fixing the gaze not on our era's light but the underbelly, or in Agamben's language 'darkness' - which shines into the staree. In this sense, the contemporary queered and cripped person, in touching an elusive imaginary sees the now and the emergent not as a death drive, but in terms of unlivedness:

... the present is nothing other than this unlived element in everything that is lived. That which impedes access to the present is precisely the mass of what for some reason (its traumatic character, its excessive nearness) we have not managed to live. The attention to this "unlived" is the life of the contemporary. (Agamben 2009, p. 51)

A cosmopolitan inclusion invokes a play where borders and limits are conceived, where "being must be conceived of as presence or absence on the basis of the possibility of play and not the other way around" (Derrida, 1967, p. 369). Whilst the flâneur in her contemporariness as the stranger arrives with questions "posing questions, making one pose questions therefore challenging the order” (Dikeç, 2002, p.227), she can only partake in inclusive encounters to the extent that she remains 'guest'. A transformed guest status depends upon a tenuous goodwill that deprives the entrenchment of heterosocial valuing. The figure of flâneur postulates about frontiers of freedom and:

... being-with-others in the modern urban spaces of the city. Freedom because the figure revolves around the dialectic of self-definition and definition from outside (although this freedom is perhaps something more by way of a curse than a promise); the meaning of (or lack of meaning) of existence because the figure is about the flux of life and the requirements to make its meaning for one’s self. (Tester, 1994, p. 8)

Disabled people need to claim back territory, refute the ableist land-grab by insisting on a sojourner status where there is present becoming. Forfeiture of the guest status (echos of recipients of care) to that of Master, even in a collectivity, presumes the non-provisional status of disability, which techno-science views as tentative (Campbell, 2009). Cosmopolitanism as comparative instantiation inscribes difference into hierarchies of those people civilised and those not. The incomprehensibility of a disability orientation is marked out in the roaming of space and the desire to follow the heteroglossia of shadows. In the next section the theme of the cosmopolitan outlook and the figure of the flâneur are brought to bear on the subject of inclusion, its paradoxes and anxieties.

\section{Paradoxes of Social Inclusion}

The quest for social inclusion whilst containing a commendable ethos holds a number of uncertain paradoxes. The 'bringing in' of inclusion can mask the fact that the Other 
is already among us, despite her unimagined presence (such as the flâneur I have already discussed). Even during the period known as the Great Confinement in Europe the vast majority of disabled people existed in the community and were not set aside (Wright, 1997). Social inclusion because of its links to sovereignty and governmentality where states of exception are decided, becomes a borderline concept, not as uncertainty but to ascertain the outermost sphere of territory, obligation and indeed humanness (c.f. Schmitt, 2005).

The deployment of a strategy of social inclusion (a form of political cosmopolitanism) becomes an immunisation against the guilt of a singular and particularised inclusion. For Esposito (2008), community and immunity are relations of "contrast and juxtaposition" (Campbell, 2008, p. ix). Hospitality assumes a governmental imperative whereby the host is in charge of territory and resources. Immunization can be a way of, an abstention from communal obligation and the "expropriative effects" and excesses of community (Campbell, 2008, p. xi). Such property relations Derrida observes compromise hospitality: "hospitality limits itself from the threshold on its own threshold, it measures it always remains at its own threshold, it governs the threshold - and in this measure it prohibits in some way crossing the threshold that it seems to allow crossing” (Derrida, 1999, p. 39). Successful crossing over must involve to a large extent some kind of alterity disavowal, a purging of difference and a submission to a hegemonic ethos.

This language of threshold also appears in the thought of Agamben to denote a journey that cannot be completed. The project to maintain the distinction between a bare (unfit) life and a good (and proper) life relies upon "the exclusion (which is simultaneously an inclusion) of bare life” (Agamben, 1998, p. 7). Hence as Norris puts it "bare life is a necessary part of the good life, in that the good life is both what bare life is not and what bare life becomes" (Norris, 2000, p. 41). Such a project does not comfortably tolerate mixtures. Hybridity under inclusion fuses into a non-descript melting pot where the particularity of differences evaporates and there is a sense of certainty in compartmentalisation. As Wendy Brown (2006) observes discourses of tolerance are engaged as part of a kit in hostility management that give an impression of inclusion but result in identity management. In effect bodies become sites for contestation and political concentration. In tolerating difference, cosmopolitanism subsumes and consumes that (inferior) difference into an unproblematic normative sameness which as Brown argues "places the object of tolerance outside the universal, positioning it as needing tolerance and hence as a lower form of life” (Brown, 2006, p. 187). We come full circle as cosmopolitanism and its reckoning with exclusion evokes an anxiety and is ungirded by a sense of guilt.

\section{The Guilt of Inclusion}

The disabled body induces a radical collision with ableist normativity and the possibility of limiting hospitality towards the 'remainders' of society (See Figure 2). This collision can distil a terror of strangeness to the thought that disability can be a possibility. On the face of it ableism, in promulgating a state of exception in the figure of the homo sacer, ${ }^{5}$ the unfit, subhuman, disordered, or perverted, who it is declared outside of life (political existence) yet included in the social order in the form of their exclusion prompts on the part of abled people an existence that operates under a permanent culpa esse, a feeling of indebted guilt in being included (c.f. Agamben 1998). Disabled people allegorically are made the sacrificial scapegoat of Leviticus 16. This guilt can be heightened when there is a greater threat or awareness about the 
provisionality of normalcy. Hence we can speak of ableism operating under a permanent guilt of inclusion.

Figure 2: "I have no one"

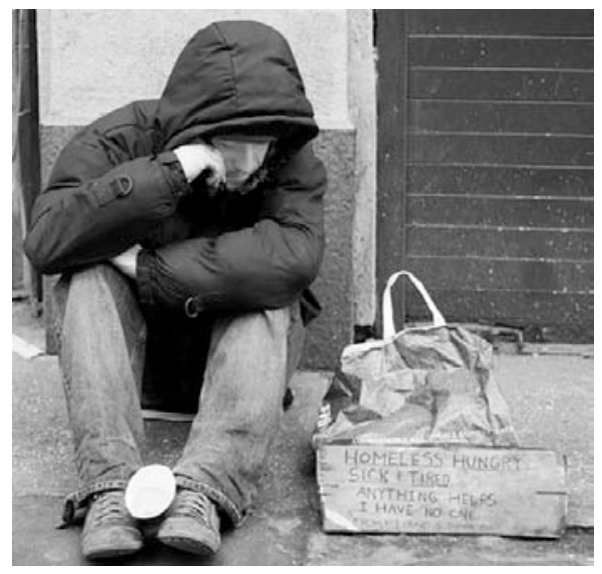

Source: Affordable Housing Institute, Boston: Accessed 10/01/2010

http://affordablehousinginstitute.org/blogs/us/wp-content/uploads/homeless_man_begging_small.jpg

Cosmopolitan hospitality while signifying openness has a trajectory, at least in Kant, of limit, allowing for the 'stranger' to be sent away provided that "...this can be done without causing his death ...” (Kant, 2007, §II, p. 18) making it quite clear that hospitality is a public event. And we know this in terms of the regulatory function of law through the police and military that invokes the public nature (publicite) to intervene in the private (prive). It is outside the purview of this article to fully consider the tenuousness of cosmopolitan hospitality however, for the record I mention three instances that have currency to matters of disablement and ableism. The first, notable group are the disabled "unrehabilitatable" who can only humanely be put in the institution or be voided by other mechanisms. ${ }^{6}$ Another sent away group are those predicted as ineffably dangerous, by use of indeterminate sentencing laws (Campbell, 1993). Finally there is the criminal who is banished through deportation, even though in the Australian situation, that person may have a regularised resident status. Emmerich de Vattel, (1714 - 1767) in Law of Peoples or Principles of Natural Law (1758) acknowledged that foreigners who might "cause ... disorder hurtful to the public welfare" could be sent off elsewhere."7

The Commonwealth of Australia Migration Act 1958, s. 201, currently allows for deportation where a person who is not an Australian citizen, has been convicted of a crime attracting at least a year's imprisonment and the crime was committed within the first ten years of the person's residence in Australia. Many of these people have mental illness or some impaired capacity. Such is the precariousness of the cripped flâneur, who if not sent away, is through economic desperation, a being-for-sale. Benjamin suggests that "the flâneur takes the concept of being-for-sale itself for a walk. Just as the department store is his last haunt, so his last incarnation is as sandwichman” (Benjamin, 1972 [1935], Vol. 5, p. 562).

The cripped flâneur is a being-for-sale to the lowest bidder. In the precarious labour market ${ }^{8}$ any job will do, for she in her desperation is fully compliant. For the disabled person, whilst she commonly takes up a position of sandwichman, the department store is rarely her haunt. Aesthetic unacceptability means she simply can't get in.

The political concept of people enshrined in the documents of the French Revolution and subsequent human rights instruments foreground two different 
conceptions - people as a whole, the social body cast against multiple excluded bodied (the aberrant) or in the alternative an inclusive whole without outsiders. As Agamben notes:

... the concept of people always already contains within itself the fundamental bio-political fracture. It is what cannot be included in the whole of which it is a part as well as what cannot belong to the whole in which it is always already included. (2000, p. 31.2)

This observation by Agamben should not come as a surprise as it was Heidegger who argued that feeling guilty is the very structure of human existence. “[Here] we derive our primordial notion of 'lack' or 'nothingness', and the experience of ourselves as lacking, incomplete, failing to live up to our-selves, our own potentials: guilty" (Heidegger, 1962, para. 284). Yet the word 'guilt' in German (schuldig wird) denotes obligation: "Someone becomes guilty in respect of another (schuldig wird) ... he causes a lack in the existence of another, that he becomes the reason for a lack of existence of another.” (Buber, 1961, p. 165)

Agamben's observations of "biopower", as one that individualizes through disciplinary practices also massifies, generalizes and normalizes by making people a population. The incitement to normalize has at its core a process of differentiation (aspiring to the norm that one does not meet). Indeed normalization as previously mentioned hinges on a belief in the minority status and enumerative containability of disabled people - rather than being conceived more as a hybrid, fluid, significant component of the bio-population where recognition of such a cohort can de-throne ableist claims to naturalization rather than a fabricated ethos. To claim inclusion one must have a permanent under-cohort of the excluded. By claiming one's own identity it must be done always in reference to that from which one is distinguished.

\section{Where to Next?}

Moral cosmopolitanism may be an antidote to the impugned version of social inclusion. Stoic thought reminds us that community is about passion, desire and openness. Emotions about belongingness and boundaries, both positive and negative do not just involve evaluative judgements but are learned and therefore need to be cultivated as part of a child's moral development (Nussbaum, 1997, p. 20). Developments in designating disability through a relational model - in the confrontation of the self and the environment, others in an internal/external dynamic challenge the dominant perspective in the western philosophical tradition that identity precedes relation, that the constitution of subjectivity is free of the other (Campbell, 2009). Beingness in relation, a relative disposition (pros ti pōs echon) - the state of one's existence is defined by something outside it (La Cugna, 1992, p. 58), hence the necessity of venturing into the world of the precarious.

Cosmopolitanism as an outlook, particularly as an urban trajectory a site for the multitude to explore diversity, can act as hubs in the government of difference whilst providing an underbelly of resistance and an alternative commentary of city life. By investigating different readings of the cosmopolitan, this paper articulates a reclamation and enactment of a version of cosmopolitanism based on gesturing toward alterity which cultivates a reflection on strangeness and the exilic life. The paper notes the tensions and flashpoints between proffering disability as offensive (to human characterisation) and cosmopolitan inclusion. Additionally further research 
and theoretical work is required on the beneficiaries of inclusion - those (en)abled people who experience, albeit unacknowledged indebted guilt at being assumptively included. It has outlined the insights of Agamben (2009) on the outlook, of whom he calls the contemporary person, a disposition that heightens the perceptiveness and grasping of one's own time. The enigmatic and elusive characterisation of the cripped flâneur becomes a point for the reflection on the civility of modernity. Engagement at the margins with the flâneurial figure may help us as Butler (2004) notes in the opening epigram to appraise the human in unlikely places. Marginal beingness provides clarity and insight into the complexity and contradictions of discourses of social inclusion.

\section{Notes}

${ }^{1}$ As late as 2009, the song "We are the World" sold more than 20 million units and raised over \$63 million for humanitarian aid in Africa and the US and was revived in 2010 as "We are the World 25 for Haiti".

2 Apropos the journal's inclusive language police, when 'man' or 'men' are used I am referring to males or retaining the historical sexed language. The gendered language of the time is based on the inference that men were primarily capable of reasoning.

${ }^{3}$ Denoting from the Greek, culture and education.

${ }^{4}$ Sometimes called negative enhancement.

5 "... who maybe killed and not yet sacrificed". (Agamben, 1998, p. 8).

${ }^{6}$ Euthanasia being an example.

7 Ugly laws have used to 'move along' the locals from pubic places. See Schweik (2009).

${ }^{8}$ The 2003 Australian Survey of Disability, Ageing and Carers, reports lower participation of people with disability in the labour force, disability decreases the probability of participation by 0.24 for males and 0.2 for females (ABS, 2004). The labour gap in participation between people with and without disability remained constant between 1988 - 2003 (AIHW, 2008). The labour force participation rate was lower (53\%) for disabled people compared to $81 \%$ for workers not identifying as having impairment. People with disability represent a significant low income population with the gross medium income per week of \$255 compared to $\$ 501$ for those not identifying as disabled. Indeed the principle source of personal income was derived by the majority of people with disability $(42.9 \%)$ is from government pensions or allowances. Only 35\% people with disability of compared with $62 \%$ of the rest of the population received a wage or salary as their principle source of income.

\section{References}

Agamben, G. (1998). Homo sacer: sovereign life \& bare life. Stanford: Stanford University Press.

Agamben, G. (1999). Remnants of Auschwitz: the witness and the archive. New York: Zone Books.

Agamben, G. (2000). Potentialities: collected essays in philosophy. Stanford: Stanford University Press.

Agamben, G. (2009). What is an apparatus? and other essays. Stanford: Stanford University Press.

Aurelius, M.A. (1919). The thoughts of Marcus Aurelius Antoninus [Meditations], (G. Long. Trans.). London: G. Bell \& Sons.

Australian Bureau of Statistics (ABS). (2004). Disability, ageing and carers: summary findings (4430.0). Canberra, ACT: Author. Retrieved from http://www.abs.gov.au

Australian Institute of Health \& Welfare. (2008). Disability in Australia: trends in prevalance, education, employment and community living. Bulletin 61, June. 
Beck, U. (2002). The Cosmopolitan society and its enemies. Theory, Culture \& Society, 19(1-2), 17 - 44.

Benhabib, S. (2004). The rights of others: aliens, residents, citizens. Cambridge: Cambridge University Press.

Benjamin, W. (1972, orig 1935). Passagen-Werk, Vol 5, in Gesammelte schrifen, (R. Tiedermann \& H. Schweppenhäaser, Ed.). Frankfurt: Verlag.

Benjamin, W. (1973). Charles Baudelaire: A lyric poet in the era of high capitalism, (Harry Zohn, Trans.). London: New Left Books.

Brown, W. (2006). Regulating aversion: tolerance in the age of identity and empire. Princeton, N.J.: Princeton University Press.

Buber, M. (1961). Between man and man. Boston: Beacon Press.

Buck-Morss, S. (1986). The flaneur, the sandwichman and the whore: the politics of loitering. New German Critique, 39, 99-140.

Butler, J. (2004). Precarious life. London: Verso.

Campbell, F. (2009). Contours of ableism: the production of disability and abledness. Basingstoke: Palgrave Macmillan.

Campbell, I. (1993). Indeterminate sentences and dangerousness, in Serious violent offenders: sentencing, psychiatry and law reform: proceedings of a conference held 29-31 October 1991, (S.Gerull \& W.Lucas,Eds) (pp. 81-95). Canberra: Australian Institute of Criminology.

Campbell, T. (2008). Translator's introduction bios, immunity, life: the thought of Roberto Esposito, in R. Esposito Bios: Biopolitics and Philosophy, Minneapolis: Minnesota University Press, vii - xlii.

Cheah, P. (2006). Inhuman conditions: on cosmopolitanism and human rights. Cambridge: Harvard University Press.

Derrida, J. (1967). Structure, sign and play in the discourse of the human sciences. Writing and difference. London: Routledge.

Derrida, J. (1999) Hostipitalité, in F.Keskin \& Ö. Sözer (Eds.), Pera peras poros: atelier interdisciplinaire avec autour de Jacques Derrida (pp. 17-44). Instanbul: YKY.

Derrida, J. (2005). On cosmopolitanism and forgiveness. London : Routledge.

Dikeç, M. Pera peras poros longings for spaces of hospitality. Theory, Culture Society, 19(1-2), 227 - 247.

Doran, E. (2009). At Hospitality's threshold: from social inclusion to exilic education, Curator, 52(2), 169 - 182.

Douzinas, C. (2007). Human rights and empire: the political philosophy of cosmopolitanism. Abingdon: Routledge-Cavendish.

Dunn, A. (2003). “Telling it like it is!”, Identities of homelessness and mental illness in inner urban Brisbane. [Masters of Human Services (Hons) Thesis]: Brisbane: Griffith University, School of Human Services.

Esposito, R. (2008). Bios: biopolitics and philosophy (T. Campbell, Trans.). Minneapolis: University of Minnesota Press.

Ewald, F. (1992). A power without an exterior, in T. Armstrong (Ed.). Michel Foucault, philosopher (pp. 169-175). New York: Harvester Wheatsheaf.

Foucault, M. (1980). Two lectures. In C. Gordon (Ed.), Foucault; power knowledge: selected interviews and other writings 1972-1977 (pp. 78-108). New York: Pantheon Press.

Foucault, M. (2008). The Birth of biopolitics, lectures at the collège de france 1978 1979, (Graham Burchell. Trans.). New York: Palgrave Macmillan.

Gleeson, B. (1999). Geographies of disability. London: Routledge. 
Goggin. G \& Newell, C. (2005). Disability in Australia: exposing a social apartheid. Sydney: UNSW Press.

Hardt, M. \& Negri, A. (2009). Commonwealth. Massachusetts: Belknap/Harvard University Press.

Harter, L.M., Berquist, C., Titsworth, B.S., Novak. D. \& Brokaw, T. (2005). The structuring of invisibility among the hidden homeless: the politics of space, stigma and identity construction. Journal of Applied Communication Research, 33(4), 305 - 327.

Heidegger, M. (1962). Being and time. (J. Macquarie \& E. Robinson, Trans.). SanFrancisco: HarperSanFrancisco.

Imrie, R. (1996). Disability and the city: international perspectives. London: Paul Chapman Publishing.

Kant, E. (2007). Perpetual peace: A philosophical Sketch. FQ Publishers, location unknown. (Original work published 1795).

Kleingeld, P. (1999). Six varieties of cosmopolitanism in late eighteenth-century Germany. Journal of the History of Ideas, 60, 505-524.

Norris, A. (2000). Giorgio Agamben and the politics of the living dead. Diacritics, 30(40), $38-58$.

Nussbaum, M. (1997). Kant and stoic cosmopolitanism. The Journal of Political Philosophy, 5(1), 1-25.

La Cugna, C. (1991). God for us. San Francisco: Harper Collins.

Overboe, J. (2007). Disability and genetics: affirming the bare life (the state of exception). The Canadian Review of Sociology and Anthropology. 44, 219235.

Poe, E. (1912). The Man of the crowd. Electronic Text Center, University of Virginia Library. Retrieved from http://etext.virginia.edu/toc/modeng/public/PoeCrow.html

Popkewitz, T. (2008). Cosmopolitanism and the age of school reform. New York: Routledge.

Rowe, M., Kloos, B., Chinman, M., Davidson, L., \& Cross, A. Boyle (2001). Homelessness, mental illness \& citizenship. Social policy \& administration 35(1), $14-31$.

Schmitt, C. (2005). Political theology, four chapters of the concept of sovereignty, (G. Schwab. Trans.). Chicago: Chicago University Press.

Seneca, L. (1987). De Otio, 4.1. (A.A. Long, Trans.) In D. Sedley (Ed), The Hellenistic philosophers. Cambridge: Cambridge University Press.

Simmel, G. (1908). The stranger. In D. Levine (Ed.), Georg Simmel on individuality and social forms. Chicago: Chicago University Press, 1971, pp. 143-149.

Schweik, S. (2009). The Ugly laws: disability in public. New York: New York University Press.

Tester, K. (Ed) (1994). The Flâneur. London: Routledge.

Vattel, E. (1758). The law of nations, or, principles of the law of nature, applied to the conduct and affairs of nations and sovereigns, with three early essays on the origin and nature of natural law and on luxury. B. Kapossy \& R. Whatmore, (Eds.). (T.Nugent, Trans.). Retrieved from http://oll.libertyfund.org/?option=com_staticxt\&staticfile=show.php\%3Ftitle= 2246\&chapter $=212459$ \&layout $=$ html\&Itemid $=27$

Westley, F. (1991). Bob Geldof and live aid: the affective side of global social innovation. Human Relations, 44(10): 1011-1036. 
Williams, A. (1997). The postcolonial flâneur and other fellow travellers: conceits for a narrative of redemption. Third World Quarterly, 18(5), 821 - 841.

Wilson, E. (1992). "The invisible flâneur". New Left Review, 191, 90 - 110.

Wright, D. (1997). Getting out of the asylum: understanding the confinement of the insane in the nineteenth century. Social History of Medicine. 10(1), 137-155.

Young, S. (2005). Morphings and ur-forms: from flâneur to driveur. Scan Journal 2(1), April. Retrieved from http://www.scan.net.au

Žižek, S. (2008). Tolerance as an ideological category. Critical Inquiry, 34(4), 660682.

\section{Biographical Note}

Dr. Fiona Kumari Campbell, is a Senior Lecturer in Disability Studies, School of Human Services \& Social Work Griffith University. She has written extensively on issues related to disability-philosophy, law, and technology and diversity. Her current research concerns ableism, geodisability knowledges, body and mental enhancements, elective impairment, advocacy, leadership \& mentoring and South Asian approaches to disability. Her work has appeared in Disability \& Society, M/C-Media and Culture, Disability Studies Quarterly, International Journal of Inclusive Education, Australian Feminist Law Journal and Journal of Medical Humanities. Her first book, 'Contours of Ableism', was published by Palgrave in October 2009. 